\title{
Behavioral, morphological, and ecological trait evolution in two clades of New World Sparrows (Aimophila and Peucaea, Passerellidae)
}

\author{
Carla Cicero $^{\text {Corresp., } 1}$, Nicholas A. Mason ${ }^{1}$, Lauryn Benedict ${ }^{2}$, James D. Rising ${ }^{3}$ \\ 1 Museum of Vertebrate Zoology, University of California, Berkeley, Berkeley, California, United States of America \\ 2 School of Biological Sciences, University of Northern Colorado, Greeley, Colorado, United States of America \\ 3 Department of Ecology and Evolutionary Biology, University of Toronto, Toronto, Ontario, Canada \\ Corresponding Author: Carla Cicero \\ Email address: ccicero@berkeley.edu
}

The New World sparrows (Passerellidae) are a large, diverse group of songbirds that vary in morphology, behavior, and ecology. Thus, they are excellent for studying trait evolution in a phylogenetic framework. We examined lability versus conservatism in morphological and behavioral traits in two related clades of sparrows (Aimophila, Peucaea), and assessed whether habitat has played an important role in trait evolution. We first inferred a multilocus phylogeny which we used to reconstruct ancestral states, and then quantified phylogenetic signal among morphological and behavioral traits in these clades and in New World sparrows more broadly. Behavioral traits have a stronger phylogenetic signal than morphological traits. Specifically, vocal duets and song structure are the most highly conserved traits, and nesting behavior appears to be maintained within clades.

Furthermore, we found a strong correlation between open habitat and unpatterned plumage, complex song, and ground nesting. However, even within lineages that share the same habitat type, species vary in nesting, plumage pattern, song complexity, and duetting. Our findings highlight trade-offs between behavior, morphology, and ecology in sparrow diversification. 
1 Behavioral, morphological, and ecological trait evolution in two clades of

2 New World Sparrows (Aimophila and Peucaea, Passerellidae)

3

4 Carla Cicero ${ }^{1}$, Nicholas A. Mason ${ }^{1}$ Lauryn Benedict ${ }^{2}$, James D. Rising ${ }^{3 \dagger}$

5

$6{ }^{1}$ Museum of Vertebrate Zoology, University of California, Berkeley, Berkeley, California,

$7 \quad$ United States of America

$8{ }^{2}$ School of Biological Sciences, University of Northern Colorado, Greeley, Colorado, United

9 States of America

$10{ }^{3}$ Department of Ecology and Evolutionary Biology, University of Toronto, Toronto, Ontario,

11 Canada $\uparrow$ Deceased March 13, 2018

12

13 Corresponding author:

14 Carla Cicero

15 Email address: ccicero@berkeley.edu. 


\section{Abstract}

19 The New World sparrows (Passerellidae) are a large, diverse group of songbirds that vary in

20 morphology, behavior, and ecology. Thus, they are excellent for studying trait evolution in a

21 phylogenetic framework. We examined lability versus conservatism in morphological and

22 behavioral traits in two related clades of sparrows (Aimophila, Peucaea), and assessed whether

23 habitat has played an important role in trait evolution. We first inferred a multi-locus phylogeny

24 which we used to reconstruct ancestral states, and then quantified phylogenetic signal among

25 morphological and behavioral traits in these clades and in New World sparrows more broadly.

26 Behavioral traits have a stronger phylogenetic signal than morphological traits. Specifically,

27 vocal duets and song structure are the most highly conserved traits, and nesting behavior appears

28 to be maintained within clades. Furthermore, we found a strong correlation between open habitat and unpatterned plumage, complex song, and ground nesting. However, even within lineages that share the same habitat type, species vary in nesting, plumage pattern, song complexity, and duetting. Our findings highlight trade-offs between behavior, morphology, and ecology in sparrow diversification. 


\section{Introduction}

36 Behavioral, morphological, and ecological traits have been used historically to reconstruct

37 evolutionary relationships, and many taxonomic groups were originally designated on the basis

38 of shared, homologous characters (e.g., Hamilton; 1962; Storer, 1955; Wolf, 1977). For example,

Lanyon $(1984 ; 1985 ; 1986 ; 1988 a ; 1988 b)$ used similarities in syringeal and cranial morphology,

plumage, nesting behavior, and foraging mode to establish generic limits and hypothesize

relationships in tyrannid flycatchers, one of the world's largest and most diverse avian radiations.

Likewise, Hamilton (1962) inferred species relationships and the origin of sympatry in the avian genus Vireo by comparing species-specific characteristics of distribution, habitat preference, foraging ecology, and external morphology. While contemporary studies of evolutionary relationships now rely largely on genetic data, studies of trait evolution in a phylogenetic framework can shed light on patterns of phenotypic evolution and diversification.

Trait lability, selective pressure, and random processes can cause traits to have different phylogenetic signals (Bloomberg, 2003; Grant \& Grant, 2002). Furthermore, variation in the rate of phenotypic evolution, as well as multiple gains or losses of a trait, can lead to patterns of character variation that differ across taxa (Dodd et al. 1999; Mooers et al., 1999). Morphology changes relatively slowly over time and is therefore thought to have stronger phylogenetic signal compared to behavior (Blomberg et al., 2003). However, behavioral traits also can have phylogenetic signal, and variation among related taxa may result from conservative or labile evolutionary processes (deQueiroz \& Wimberger, 1993; Cicero \& Johnson, 1998, 2002; Price \& Lanyon, 2004; Brumfield et al., 2007; Price et al., 2007; Kamilar \& Cooper, 2013; Barve \& Mason, 2015; Anderson \& Wiens, 2017; Fang et al., 2018). 
59 Molecular phylogenies facilitate tests of how traits evolve within clades. For example,

60 mitochondrial DNA (mtDNA) sequences for the Empidonax group of tyrant flycatchers are

61 congruent with morphological, behavioral, and allozymic traits, although some behaviors such as

62 nesting and migratory tendency have stronger phylogenetic signal than others such as foraging

63 mode (Lanyon, 1986; Cicero \& Johnson, 2002a). In Icterus orioles, song and plumage evolution

64 are highly labile between species but conserved across the genus as a whole. Furthermore,

65 Icterus songs are more labile than those in closely related oropendolas (Psarocolius, Ocyalus),

66 which tend to have conserved song characteristics (Price et al., 2007).

The New World sparrows (Passerellidae, formerly Emberizidae) are a large, diverse lineage of songbirds that are excellent for studying trait evolution in a phylogenetic framework.

Evolutionary studies of New World sparrows include analyses based on morphology, plumage, soft-part colors, behavior, egg coloration, allozymes, mitochondrial and nuclear gene sequences, and phylogenomic data from ultraconserved elements (Wolf, 1977; Patten \& Fugate, 1998;

Carson \& Spicer, 2003; DaCosta et al., 2009; Klicka \& Spellman, 2007; Klicka et al., 2014;

Bryson et al., 2016; Sandoval et al., 2017). Although comparisons among these studies are compounded by differences in taxon and character sampling, together they provide a valuable

framework for studying sparrow evolution. Whether behavioral traits are more labile (Blomberg et al., 2003) or conserved (Brumfield et al., 2007) than morphological traits in sparrows remains an open question that deserves study.

One especially interesting group is the historical genus Aimophila, which has been plagued by taxonomic uncertainty due to extensive morphological variation. Members of this group were 
82 originally united by characteristics of the bill, wings, tail, and feet (Swainson, 1837; Baird, 83 1858), but other ornithologists have long thought that they represent species from distantly

84

85

86

2

related lineages (Ridgway, 1901; Dickey \& Van Rossem, 1938; Storer, 1955; Wolf, 1977).

Within the past decade, molecular data (e.g., DaCosta et al., 2009; Klicka et al., 2014; Sandoval et al., 2017) have clarified relationships and demonstrated polyphyly of the "Aimophila" group.

This spurred a taxonomic revision (Chesser et al., 2010; Remsen et al., 2010) that placed species formerly classified as Aimophila into one of three genera (Aimophila, Peucaea, Rhynchospiza), recognized the alliance of "Aimophila" quinquestriata with the genus Amphispiza, and moved some taxa from the genus Pipilo to Melozone. Furthermore, species of Aimophila, Melozone, and Pipilo form a clade separate from Peucaea and Rhynchospiza.

Prior to molecular phylogenetic studies, species relationships in Aimophila sensu lato were hypothesized based on detailed study (Wolf, 1977) of behavioral, morphological, and ecological differences that grouped taxa into one of three ecological "complexes": (1) Haeomophila complex (currently Peucaea: species ruficauda, sumichrhasti, humeralis, mystacalis, carpalis), which radiated in lowland thorn scrub forests of western Mexico and the Pacific lowlands of Central America, and are characterized by simple songs, chatter duets derived mostly from primary songs, prenuptial molt, raised nests, heavy bills, patterned adult plumages, juvenile plumages more similar to adults than in other groups, and mostly delayed skull ossification; (2) botterii complex (also Peucaea: species aestivalis, botterii, cassinii), which occupy weedy, open country in Central and North America, have dull plumages (often with yellow at the bend of the wing), are migratory with more pointed wings, sometimes have spotted first-year plumages, and sing complex songs with chitter duets; and (3) ruficeps complex (currently Aimophila: species 
105

106

107

108

109

110

111

112

113

114

115

116

117

118

119

120

121

122

123

124

125

126

ruficeps, rufescens, notosticta), which radiated in pine-oak woodlands of Mexico and Central

America and have similar primary songs, chatter duets not derived from primary song, and

similar plumage patterns with rusty head stripes or caps. Wolf (1977) also described the

geographic distribution of each species, and noted that range sizes vary within ecological

complexes. On the basis of behavioral similarities, Wolf (1977) suspected a close relationship

between the ruficeps complex and towhees in the genus "Pipilo" (now Melozone) - a

hypothesis since supported by molecular data (Spicer \& Carson, 2003; DaCosta et al., 2009;

Klicka et al., 2014). He was uncertain about the placement of another species quinquestriata

because of its unique plumage and song traits, and did not include two South American species

(currently Rhynchospiza: species stolzmani and strigiceps) in his study.

The detailed phenotypic analysis by Wolf (1977) provides an opportunity to revisit questions about trait evolution (Maddison, 1994) within the two clades of Aimophila (plus Melozone and Pipilo) and Peucaea (plus Rhynchospiza) in a modern phylogenetic comparative framework. In this study, we focus on whether behavior, morphology, and/or ecology exhibit phylogenetic signal in these two clades, and extend these ideas to a larger group of New World sparrows. Specifically, we ask which traits identified as informative by Wolf (1977) are phylogenetically conservative or labile. We also use these data to assess the extent to which behavioral and morphological traits are associated with open (grassland) versus closed (arid scrub or pine oak) habitat types. If we find a strong association, then species in the same habitat type (i.e., same ecological group) may have been subjected to either phylogenetic niche conservatism (Pyron et al. 2015) or similar selective pressures that drive local adaptation to the environment 
127 (Lenormand 2012). In either case, we would predict that traits are more conserved among species

128 in similar habitats than among those in different habitats.

\section{Material \& Methods} DNA sequencing

132 We constructed an independent phylogeny of sparrows with a focus on all species formerly in the genus Aimophila, which are now divided into three genera: Peucaea (22 samples), Aimophila (8), and Rhynchospiza (4). We also included samples of Pipilo (9) and Melozone (4) because of their relatedness to the ruficeps complex based on both behavioral (Wolf, 1977) and molecular (DaCosta et al., 2009) data. In addition, we sequenced two individuals of Amphispiza quinquestriatia, which has been classified either in Aimophila (Dickinson, 2003) or Amphispiza (Chesser et al., 2010), along with Amphispiza bilineata (3) and a former congener Artemisiospiza belli (2) that is now placed in a monotypic genus (Klicka \& Spellman, 2007; Chesser et al., 2010; Klicka \& Banks, 2011). Using other phylogenetic studies of "Aimophila" and passerellid sparrows (Carson \& Spicer, 2003; DaCosta et al., 2009; Klicka et al., 2014; Bryson et al., 2016) as a framework for comparison, we added species in 10 other sparrow genera: Arremon (4), Chondestes (2), Oriturus (2), Spizella (4), Pooecetes (2), Ammodrammus

144 (4), Ammospiza (2), Passerculus (2), Arremonops (2), and Zonotrichia (2). In total, we included 14580 samples from 43 species in the Passerellidae and 4 non-sparrow outgroups (2 Parulidae, 2 146 Icteridae; Table S1).

We extracted genomic DNA from tissue using a modified salt extraction procedure (Miller et al., 1988), and PCR-amplified and sequenced four protein-coding mitochondrial genes (cyt- $b, \mathrm{ND} 2$, 
150 ATPase 8, COI) and three nuclear gene regions (intron 5 of transforming growth factor beta 2

151 [TGFb2] and beta-fibrinogen [Fib5], recombination activating gene RAG-1) using various

152 combinations of primers (Table S2). We focused on the core ingroup taxa and putative allies for

153 all loci (total of 5344 bp: 3495 mtDNA, 1849 nDNA), and added mtDNA sequences from

154 GenBank to fill out the taxon sampling (Table S1). PCR-amplification and sequencing were

155 generally successful except for a few samples at some loci. We amplified DNA in $25 \mu \mathrm{L}$

156 reactions with a mixture of $2 \mu \mathrm{L}$ dNTPs $(2 \mathrm{mM}), 2.5 \mu \mathrm{lBSA}(10 \mathrm{mM}), 1.5 \mu \mathrm{L}$ of each primer

157 pair $(10 \mathrm{mM}), 2.5 \mu \mathrm{L}$ of buffer $(10 \mathrm{x})$ pre-mixed with $\mathrm{MgCl} 2,0.1 \mu \mathrm{L}$ of Taq polymerase, $1 \mu \mathrm{L}$ of

158 DNA, and double-distilled water. Amplification steps included an initial denaturation at $93^{\circ} \mathrm{C}$ for

1594 min followed by $30-35$ cycles of denaturation $\left(93^{\circ} \mathrm{C}\right.$ for $\left.30 \mathrm{~s}\right)$, annealing $\left(42-50^{\circ} \mathrm{C}\right.$ for $\left.30 \mathrm{~s}\right)$,

160 and extension $\left(72^{\circ} \mathrm{C}\right.$ for $\left.45 \mathrm{~s}\right)$, and a final extension at $72^{\circ} \mathrm{C}$ for $5 \mathrm{~min}$. Reactions had at least one

161 negative and often a positive control, and we visualized PCR products on agarose gels stained

162 with ethidium bromide. Following amplification, we cleaned the PCR products with Exonuclease

163 I and Shrimp Alkaline Phosphatase (ExoSAP-IT, US Biochemical Corp.), and sequenced the

164 purified products in both directions using Big Dye terminator chemistry v. 3.1 and an AB

165 PRISM 3730 DNA Analyzer (Applied Biosystems). We checked and aligned all sequences using

166 CodonCode Aligner v. 4.0.3 (CodonCode Corporation).

\section{Phylogenetic analyses}

169 We constructed phylogenetic trees using all 80 ingroup and 4 outgroup samples (Table S1) with

170 mitochondrial and nuclear loci by performing Bayesian and maximum-likelihood concatenated

171 analyses alongside species-tree inference. For the concatenated analyses, we first identified the

172 best-performing model of sequence evolution for each locus and codon position for gene regions 
173 via Akaike Information Criterion with MrModeltest v. 2.3 (Nylander, 2004). We then

174 constructed Maximum Likelihood (ML) phylogenies using RAxML v7.0.4 (Stamatakis, 2006;

175 Stamatakis et al., 2008), in which we performed 100 iterations of rapid bootstrapping while

176 simultaneously finding the best tree in a single run with a GTR + I + G model of nucleotide

177 substitution for each locus or gene region. We used BEAST v2.5.1 (Drummond \& Rambaut,

178 2007; Drummond et al., 2012; Bouckaert et al., 2014) on the CIPRES Science Gateway (Miller

179 et al., 2010) to conduct concatenated analyses in a Bayesian framework, in which we linked an

180 uncalibrated clock model across loci but applied a separate HKY + I + G model of nucleotide

181 substitution to each locus. We linked the tree prior for all loci and implemented a Yule model of

182 speciation. We selected the Yule model because it is the simplest model of speciation, in which

183 each lineage is assumed to have the same constant speciation rate, and is also appropriate for

184 inferring phylogenies among species rather than among populations within species

185 (https://www.beast2.org). We ran the BEAST analysis for 1 x $10^{8}$ generations while sampling

186 every 1000 generations. We discarded the first $10 \%$ of sampled generations as burn-in, and

187 assessed convergence and mixing by ensuring ESS scores for each parameter exceeded 300 in

188 Tracer v1.7.5.

189

190 We conducted a species-tree analysis using the *BEAST package within BEAST v2.5.1

191 (Bouckaert et al., 2014). For this analysis, we implemented a Yule speciation model and a

192 constant population model with estimated population sizes for each gene tree and the resultant

193 species tree. We ran the species-tree analysis for $1 \times 10^{9}$ generations and removed the first $10 \%$

194 as burn-in. For both the BEAST and *BEAST analyses, we subsequently generated maximum 
195 clade credibility trees from a thinned set of 5000 trees that was sampled every 20,000 or 200,000

196 generations, respectively.

197

198 Trait reconstructions

199 We scored 12 trait variables (9 binary and 3 multi-state) for each species (Table S3). Of these, 11 200 traits were described in detail by Wolf (1977) and we followed his scheme in assigning values as 201 closely as possible. These included range size, typical habitat, plumage "brightness" (hereafter 202 referred to as patterning), completeness of the postjuvenal molt, presence of a prenuptial molt, 203 nest position, timing of skull ossification, group breeding, song structure, duetting, and duet type.

204 We added geographic distribution as an additional trait in order to reconstruct its history in our 205 focal clades. We assigned trait values based primarily on published information, which we took 206 directly from Wolf (1977) for the species that he included, but we had to interpret and 207 standardize definitions for some traits (e.g., range size, plumage patterning, song complexity) 208 and for species not studied by Wolf. We used available audio recordings (Wolf, 1977 LP of 209 audio recordings; Macaulay Library) to characterize song structure.

210

211 Binary traits used in trait reconstructions and tests of phylogenetic signal are described as 212 follows:

213 (1) Plumage patterning: Unpatterned species are generally black or tan, but may show small 214 patches of color or clearly delineated markings, such as the facial patterns on Aimophila 215 sumichrasti. Patterned species have large patches of color that differ from the rest of the body. 
(2) Postjuvenal molt: This molt is complete in species where individuals molt the entire

217

218

219

220

221

222

223

224

225

226

227

228

229

230

231

232

233

234

235

236

237

238

plumage at this life stage, and incomplete in species where individuals molt only part of the plumage.

(3) Prenuptial molt (also known as prealternate molt, which occurs before breeding in certain birds): This molt is present in some species and absent in others.

(4) Skull ossification: Normal species have fully ossified skulls by the end of the first year. Skull timing is delayed in species where this process takes longer than one year.

(5) Nest position: Ground nesters typically build their nests on the ground. All species that build nests off the ground, regardless of height, are considered to have raised nests.

(6) Group breeding: Species where more than a pair of adults occur together during the breeding season are considered to have groups. For example, Wolf (1977) characterized Aimophila ruficauda as having groups because he observed one female, one adult male, and additional first year males in the same breeding flock. This differs from other species where a single pair occurs on a territory. We scored group breeding as present only if the species frequently or regularly breeds in groups.

(7) Song structure: Song structure determinations followed Wolf(1977), other published reports (e.g., Rodewald, 2015), and examination of sound files (Table S3). Simple songs consist of one to four note types, although the notes may be repeated many times. They include songs with consistent syntax, including those that begin with a few introductory notes followed by a trill. Complex songs include a variable array of frequency-modulated note types and syntactical constructions.

(8) Duetting: Two individuals duet when they time their vocalizations to occur simultaneously or alternatively in a predictable manner. 
239

240

241

242

243

244

245

246

247

248

249

250

251

252

253

254

255

256

257

258

259

260

261

(9) Geographic distribution: Northern Temperate species have breeding ranges in North America. Middle American species breed from Mexico through Panama.

Multiple-state traits used in trait reconstructions are described as follows:

(10) Range size: We followed Wolf (1977)'s characterization of species as having small, medium, or large breeding ranges, which we measured from his published distribution maps as ca. $240 \mathrm{~km}$ long at the longest diameter, $240-800 \mathrm{~km}$ long, and over $800 \mathrm{~km}$ long, respectively.

This trait, in combination with distribution, reflects geographic patterns of diversity and environmental tolerance (Stevens 1989). Some species such as Aimophila notosticta, which is confined to the mountains of central and northern Oaxaca, have much more restricted ranges than other widespread taxa.

(11) Habitat: Arid scrub species coincide with Wolf's (1977) "thorn-scrub" category and live mostly in dry environments characterized by low, bushy vegetation. Pine-oak species live in woodlands that may be dominated by pine and/or oak trees. Grassland species live in open environments with predominantly grassy, herbaceous vegetation. Although this character has three states, we converted it to binary for trait correlation analyses. We designated grassland as "open" habitat, and both thorn-scrub and pine-oak as "closed" habitat (Boncoraglio and Saino 2007).

(12) Duet type: We used Wolf's (1977) named duet types to indicate duet structure, and only included character states for species that he coded because these designations are somewhat subjective. Squeal duets have broadband elements that sound like squeals. Chitter and chatter duets have similar brief broadband ticking elements. Aimophila carpalis gives a unique "warbled" (Wolf 1977) duet. 
263 We used the BEAST maximum clade credibility tree (ML showed the same topology) with the

264

265

266

267

268

269

270

271

272

273

274

275

276 concatenated mtDNA and nDNA dataset to estimate character transition rates and reconstruct ancestral character states. We reconstructed character states on our tree with all samples as well as in the two clades of Peucaea (colored blue in Fig. 1) and Aimophila plus the closely related genera Melozone and Pipilo (colored pink in Fig. 1). We performed ancestral state reconstructions of our categorical traits using a model-fitting approach that allowed for polymorphic character states within the package corHMM (Beaulieu et al., 2017). Polymorphic character states were assigned likelihoods following the methods of Felsenstein (2004), with each possible character assigned an equal probability. This allowed us to estimate the phenotype of ancestral nodes while incorporating uncertainty in species' phenotypes that were based on missing or incomplete data. We implemented an 'equal rates' model, in which transition rates between any character state were assumed to be equal with an upper bound of 100, while the character state of the root for each group was estimated following differential equations put forth by Maddison et al. (2007) and FitzJohn et al. (2009). After estimating the transition rate matrix, we subsequently calculated the marginal likelihood states at each node.

We used Pagel's (1994) correlation method in Mesquite to test Wolf's hypothesis that individual traits vary in association with habitat for Peucaea. In this group, we tested for associations of prenuptial molt, nest location, song structure, and plumage patterning with open and closed habitat. We did not test other traits such as molt or skull ossification because we had no a priori predictions about their relationships, and we lacked the required information for all taxa.

Because this test requires binary character states, we did not test non-binary traits. All members 
285 of the Aimophila clade live in closed habitat, so within-clade tests for effects of habitat are

286 uninformative; however, we tested for a relationship between song complexity and plumage

287 patterning in that group. We ran tests with 10 extra iterations over 10,000 simulations. Extra

288 iterations implement additional searches within the maximum likelihood framework, and the

289 simulation number is used to estimate statistical significance, with higher numbers above 100

290 returning better p-value estimates based on simulation output (Maddison \& Maddison, 2018).

291 Because the tests of Wolf's specific hypotheses were done on small samples, we followed up on

292 some of the associations they revealed by using the same correlation method to relate song with

293 plumage and habitat use for all species in the tree. We were unable to evaluate additional traits in

294 this way because of missing data across the full tree.

295

296 We examined trait lability among all species in the full tree for a subset of behavioral and

297 morphological traits by calculating the $D$ statistic, which is suitable for binary, categorical traits

298 (Fritz \& Purvis, 2010), using the function phylo.d within the caper package in R (Orme, 2018).

299 Binary traits included in these analyses included plumage patterning, postjuvenal molt,

300 prenuptial molt, skull ossification, nest position, group breeding, song structure, and duetting.

301 The bounds of the $D$ statistic depend on the number of tips in the phylogenetic comparative

302 analysis, but in general, more negative values imply stronger phylogenetic signal (Fritz \& Purvis,

303 2010). The $D$ statistic is calculated by comparing the sum of observed sister-clade differences in

304 the evolutionary history of the binary trait $\left(\sum d_{o b s}\right)$ to simulated data sets of sister-clade

305 differences generated by randomly shuffling the tip values of the phylogeny $\left(\sum d_{r}\right)$ and another

306 simulated data set generated by Brownian motion $\left(\sum d_{b}\right)$. Thus, $D$ is comparable across data sets

307 such that when $D$ is equal to 1 , the binary trait in question has a phylogenetically random 
308 distribution across the tips of the phylogeny. In contrast, when $D$ is equal to 0 , the distribution of

309 binary values across the tips is equal to that expected under Brownian motion (Fritz \& Purvis,

310 2010). Furthermore, values of $D$ can fall outside of the range of 0 to 1 , such that negative values

311 indicate phylogenetic conservatism beyond that expected by Brownian motion, while values

312 greater than 1 indicate phylogenetic dispersion beyond that expected by random shuffling of tip

313 values (Fritz \& Purvis, 2010). This method also allows one to calculate two separate one-tailed

314 probabilities (i.e., $p$ values) that the observed $D$ statistic is greater than 0 and less than 1 . For

315 each trait, we omitted taxa with unknown or ambiguous character states.

316

317 Results

318 Sequence variation

319 The complete data set of 84 individuals from 47 species and up to 5344 bp of sequence contained 3201740 variable (32.6\%) and $1546(28.9 \%)$ potentially parsimony-informative sites. The two clades 321 for which we reconstructed character states had 1324 (24.8\%) variable and $1188(22.2 \%)$

322 parsimony-informative sites. Average nucleotide composition for the mitochondrial genes cyt- $b$

323 and ND2 were similar to values reported in previous studies of this group and related taxa

324 (Klicka \& Spellman, 2007; DaCosta et al., 2009), with an excess of cytosine (36\%) and a 325 deficiency of guanine (10-13\%). Average uncorrected sequence distances among core taxa for 326 the mitochondrial gene regions were $11 \%$ in Peucaea (6.6-14.8\%) and 4.9\% in Aimophila (3.7\%-

327 6.1\%). The mean distance between Aimophila and the closely related genera Melozone and 328 Pipilo was $9.1 \%$ (range of $7.7 \%$ to $11.5 \%$ ). 
331 Maximum likelihood (Fig. S1) and Bayesian methods (Fig. 1) of phylogenetic reconstruction

332 produced similar phylogenetic hypotheses, with the strongest support obtained for the

333 concatenated analysis of mtDNA and nuclear sequence data (Fig. 1). With the exception of three genes (ATPase 8, Fib 5, TGFb2), the best model was GTR + I + G for the data partitioned by loci, mtDNA partitioned by codon position, and combined mtDNA and nDNA sequences. With all samples combined, taxa grouped into two lineages that received high to moderate support in the phylogenetic analyses. The first lineage included Peucaea, Rhynchospiza, Arremonops, and Ammodramus. Within that lineage, the eight species of Peucaea formed a monophyletic group that was strongly supported and distinct from Rhynchospiza and the other genera. The second lineage included species in multiple genera, with a strongly supported clade that united species retained in Aimophila with species of Melozone and Pipilo. The species quinquestriata was sister to Amphispiza bilineata in a lineage that included Chondestes and Spizella, and those taxa were distant to the clade containing Aimophila. The species tree analyses generated a phylogeny that was concordant with the concatenated approaches and many of the same relationships were recovered (Fig. S2). However, the resultant species tree did not have strong posterior probability values for the large majority of nodes, which likely reflects the relatively small number of loci and the small number of individuals per species used in the coalescent-based species tree analysis (Camargo et al., 2012; Fig. S2). A species tree constructed with many more loci also was not able to resolve all relationships within the family (Bryson et al., 2016).

\section{Trait reconstructions: Peucaea and Aimophila clades}

Ancestral state reconstructions (Fig. 2 through Fig. 5) show that both the Peucaea and Aimophila clades originated in Middle America (Fig. 2), with some members of each clade shifting their 
354

355

356

357

358

359

360

361

362

363

364

365

366

367

368

369

370

371

372

373

374

375

376

ranges northward into the Northern Temperate zone. Aimophila species descended from a common ancestor that is predicted to have a large geographic range and a preference for pineoak (closed) habitat (Figs. 2 and 3). We were unable to reconstruct the geographic range and habitat preference of ancestral Peucaea species unequivocally.

Molt patterns, plumage patterning, and timing of skull ossification showed different histories in the two clades. The ancestral species in both clades had partial postjuvenal molts, but they differed in the presence (Peucaea) or absence (Aimophila) of a prenuptial molt (Fig. 4).

Prenuptial molt has been lost once in Peucaea, and gained twice within the broader Aimophila clade. Evolutionary patterns of plumage coloration likewise differed between clades (Fig. 4). The ancestral Peucaea had unpatterned plumage, and there has been a single transition to patterned coloration in one descendant lineage. In contrast, the Aimophila clade shows more uncertainty, with multiple probable transitions between unpatterned and patterned plumage. While the ancestral Aimophila species had normal skull ossification timing, the skull timing of the Peucaea ancestor is uncertain and there is diversity in this trait among modern lineages (Table S3). Three Peucaea species form a clade with normal skull timing, three species form a clade with delayed skull timing, and a third clade is split with one species in each category.

Ancestral state reconstructions of behavioral traits also showed different patterns. Most species in the two clades live in pairs and do not form larger social groups (Table S3). The only exceptions are P. ruficauda and P. humeralis. Because their close relative $P$. mystacalis does not form groups, the presence of groups in P. ruficauda and P. humeralis may represent separate gains of the trait or a single gain with a subsequent loss of the trait in P. mystacalis. The 
377 ancestral nest type for Peucaea is a raised nest (Fig. 3), while the ancestral nest type for

378 Aimophila is equivocal. However, members of both clades use both nest locations. Simple songs

379 are the ancestral condition in both clades, with complex songs evolving once among the Peucaea

380 group and twice among the Aimophila group (Fig. 5). Many members of both clades produce

381 vocal duets (Fig. 5). Duetting clearly represents an ancestral condition among Peucaea species

382 that is highly conserved, while duets have been lost at least twice within the Aimophila clade (A.

383 notosticta, Pipilo). Furthermore, duet type shows phylogenetic conservatism in acoustic structure

384 (Fig. 5). Peucaea species all sing rapidly modulated "chitter," "chatter," or "warble" duets, while

385 all members of the Aimophila group with well-described duets produce broadband "squeal" 386 duets.

387

388

389

390

391

392

393 simple song is correlated with patterned plumage $(\mathrm{p}=0.021)$.

396

397

398

399

Across our full tree (Fig. 1), unpatterned coloration is correlated with transitions into open habitats $(p=0.026)$, mirroring the results within our two focal clades. Song structure did not correlate with transitions to or from open $(\mathrm{p}=0.746)$ habitat. Plumage patterning correlated with 
400 song complexity such that patterned birds tended to have simpler songs $(\mathrm{p}=0.045)$ across all 401 species in our tree.

\section{Measures of trait lability}

To examine the lability of behavioral and morphological traits among sparrows through time, we estimated character state changes for eight traits using our full tree that included a broader sampling of our two focal clades and related taxa without missing data (Table 1). We found a range of estimated $D$ values, indicating variation in phylogenetic signal among behavioral and morphological traits. For the behavioral traits we examined, presence or absence of duetting behavior exhibited the strongest phylogenetic signal $(D=-1.72)$, while group breeding behavior exhibited the weakest phylogenetic signal $(D=1.17)$. Among the morphological traits, skull ossification exhibited the strongest phylogenetic signal $(D=-1.21)$, while plumage patterning exhibited the weakest phylogenetic signal $(D=0.56)$. On average, phylogenetic signal was stronger among the four behavioral traits (mean $D=-0.71$ ) compared to the four morphological 414 traits (mean $D=-0.31)$.

\section{Discussion}

\section{Phylogenetic relationships of the Peucaea and Aimophila clades}

418 We found similarities and differences from prior phylogenies of New World Sparrows (DaCosta 419 et al., 2009; Klicka et al., 2014; Bryson et al., 2016; Sandoval et al., 2017). Overall, our results 420 support division of the former "Aimophila" into Peucaea, Rhynchospiza, and Aimophila, but the 421 phylogenetic details differ. For one, we found Peucaea carpalis and P. sumichrasti to be sister to 422 the remaining Peucaea with over 95\% posterior probability (PP) support in the concatenated 
423 analysis (Fig. 1), while DaCosta et al. (2009) could not resolve this relationship; however,

424 support was lower in our species tree (Fig. S2) and in the maximum likelihood tree of Klicka et

425 al. (2014). Another difference was in the clade containing Aimophila rufescens, A. ruficeps, and

426 A. notosticta. While DaCosta et al. (2009) and Klicka et al. (2014) found strong support for a

427 sister relationship between A. notosticta and A. ruficeps based on mtDNA when all three taxa

428 were included, we recovered a sister relationship between A. ruficeps and A. rufescens using both 429 mtDNA and nuclear markers in our concatenated analysis ( $\mathrm{PP}>0.95)$. Our species tree analysis, 430 on the other hand, was unable to resolve the relationships between these three taxa. The different 431 studies all supported a sister relationship between Aimophila, Melozone, and Pipilo, although 432 Sandoval et al. (2017) did not recover monophyly within Melozone (i.e., some species are more 433 closely related to Aimophila than other congeners) with more intensive sampling of that genus. 434 We also confirmed that quinquestriata is the sister to Amphispiza bilineata, although these taxa 435 are separated by a deep branch and both are distantly related to both "Aimophila" and 436 Artemisiopiza (formerly Amphispiza) belli; none of the prior studies included all three taxa in 437 their analyses. Finally, we found Peucaea and relatives to be sister to other sparrows sampled, 438 while Bryson et al. (2016) found the Amphispiza lineage to be sister to other sparrows, including 439 Peucaea, based on UCE sequence data. Together, these studies offer a compelling overview of 440 species relationships among Aimophila, Peucaea, and related sparrow taxa, although additional 441 work is needed to resolve some relationships. Furthermore, they clarify relationships in the three 442 ecological complexes that Wolf (1977) defined, including support for a close affinity between 443 the Aimophila ruficeps complex and species in the genus Melozone. 
446 All species in the Aimophila and Peucaea clades have Middle American ancestors. The ancestor

447 of the Aimpophila clade had a large range size, but range size was equivocal in the Peucaea

448 clade and reflected high variability among those species. Wolf (1977) noted that species in this

449 clade had ranges centered around Mexico, with possible Middle America origins, and pointed

450 out that closely related species varied in range size. Our analyses support these ideas and

451 highlight the variability in range location and size within the group. Four of the eight Peucaea

452 species have expanded (3) or moved (1) their ranges from ancestral Middle America to Northern

453 Temperate locations. Six of the twelve Aimophila/Melozone/Pipilo species also have expanded

454 (4) or moved (2) their ranges into Northern Temperate regions. Anecdotally, none of the species

455 that showed range shifts are long-distance migrants, but northern temperate species tend to have

456 larger ranges (Howell and Webb, 1995). These results fit with recent work showing that the

457 common ancestor of all species in Passerellidae was likely a tropical endemic (Winger et al.,

458 2014). The findings also support Rapaport's rule, which states that high latitude species tend to

459 have larger ranges than low-latitude species (Stephens, 1989; Cicero and Johnson, 2002b).

460

461 Ancestors of Aimophila and Peucaea sang simple songs and formed pair bonds. Subsequently,

462 group living evolved only in Peucaea humeralis and P. ruficauda, while complex songs evolved

463 three times and are now present in seven of our modern focal species (Fig. 5). Wolf (1977) used

464 song and duet similarity as a justification for grouping species together, and our phylogeny

465 supports those groupings while confirming that shifts in song form occur primarily between but

466 not within groups. Likewise, Marshall (1964) concluded that voice is a good predictor of

467 relationships within the "brown towhee" complex (Melozone fusca, M. crissalis, M. aberti, M.

468 albicollis), especially when used with other attributes. Song structure is known to vary widely 
469 across avian species, and other work has shown that song traits may be both conserved and 470 divergent within and among groups (Price \& Lanyon, 2002; Price et al., 2007; Snyder \&

471 Creanza, 2019). Importantly, Wolf”s (and hence our) divisions of songs into "simple" and

472 "complex" reflect only two potential measures of complexity - syllable type diversity and

473 syntax. Because we followed Wolf's trait assignments, these categories are qualitative. More

474 detailed and quantitative song-form analyses would be a valuable follow-up to this work, and

475 might show that elements of song complexity are differentially conserved or labile through

476 evolutionary time (Benedict \& Najar, 2019).

477

Ancestral habitat use and nesting behavior varied between clades, as did skull ossification timing, molt patterns, and plumage. The Aimophila common ancestor might have had patterned plumage, while the Peucaea ancestor was likely unpatterned. Modern species in both groups show a range of plumage patterns, which appear to be relatively labile suggesting that color patterning can both appear and disappear. Similar trends have been found in other avian species and across birds more generally (Price et al., 2007; Hoffman et al., 2008; Dunn et al., 2015; Maia et al., 2016; Shultz \& Burns, 2017; Marcondes \& Brumfield, 2019), showing that evolution may favor elaborate plumage or drabness depending on selective pressures. In addition, there appears to be a negative association between plumage patterning and song complexity, both within our focal clades and across our full phylogeny. Two lineages that contain species with complex songs (Peucaea cassinii-P. aestivalis-P. botteri and Aimophila rufescens-A. ruficeps-A. notosticta) are characterized by unpatterned plumage, while species in other lineages with simple songs (e.g., Peucaea mystacalis, P. humeralis, P. ruficauda) have patterned plumage. Other 491 studies on the evolution of plumage and song complexity in birds have shown that some groups 
492 (e.g., cardueline finches, Badyaev et al., 2002) exhibit a similar trade-off whereas other groups

493 (e.g., tanagers, Mason et al., 2014) do not show a correlation between song and plumage

494 elaboration. Such mixed results suggest that the relationship between song and plumage likely

495 depends on a variety of factors, which may include physiological processes (Shutler, 2010) or

496 ecological interactions.

497

498 Song complexity may be greater in open versus densely vegetated habitats because of the

499 acoustic properties of those habitats (Morton, 1975; Wolf, 1977; Wiley, 1991; Derryberry, 2009;

500 Mason \& Burns, 2015; Derryberry et al., 2018; Crouch \& Mason-Gamer, 2019; but see Karin et

501 al., 2018 and Hill et al., 2017). Within the Aimophila and Peucaea clades, we found that complex

502 songs are significantly associated with open grassland habitat, and simple songs are associated

503 with closed (arid scrub or pine-oak) habitat. Such a relationship may result from habitat

504 structure, but might also arise because more grassland species (Peucaea botteri, P. cassinii, $P$.

505 aestivalis) occur in Northern Temperate latitudes where they experience higher environmental

506 variability, which is known to influence bird song complexity (Medina \& Francis, 2012; but see

507 Najar \& Benedict, 2019). We did not, however, recover the same relationship when all species

508 were included. Therefore, we have tentative support for Wolf's (1977) hypothesis that habitat

509 drives song features within the focal clades, but his observed trend is not universal. It is possible

510 that the observed correlations between habitat and song within the Aimophila and Peucaea

511 clades results from small samples sizes, because a small number of trait transitions drive these

512 correlations (Maddison \& FitzJohn, 2015).

513 
514 Color evolution is often driven by habitat type, with natural selection favoring certain colors,

515 patterns, or lack of patterning (Dunn et al., 2015; Shultz \& Burns, 2013; Marcondes \&

516 Brumfield, 2019; Miller et al., 2019). However, a global analysis showed that habitat does not

517 predict plumage patterns across birds as a whole (Somveille et al., 2016). We found that

518 unpatterned plumage correlated with open grassland habitat among members of the Aimophila

519 and Peucaea clades, as well as when trait correlation analyses were run using the full tree. Thus,

520 unlike Wolf's (1977) ideas about the influence of habitat on song, his hypotheses regarding

521 habitat and plumage evolution appear to apply broadly within the Passerellidae. Unpatterned

522 coloration can be advantageous for crypsis in open grassland habitats (Hill \& McGraw; 2006),

523 Our findings - along with studies of other specific groups such as woodpeckers (Miller et al.,

524 2019) and ovenbirds (Marcondes \& Brumfield, 2019)—suggest that the influence of habitat on

525 plumage patterning may be clade-specific.

526

527 Lability versus stability of behavioral and morphological traits

528 Although behavioral traits are expected to be more labile than morphological traits (Blomberg et

529 al., 2003), we found that the behavioral traits identified by Wolf (1977) exhibited stronger

530 phylogenetic signal across our full tree than the morphological traits (Revell et al., 2008). In

531 particular, prenuptial molt and plumage patterning showed low phylogenetic signal and high

532 lability. This result is counterintuitive for the prenuptial molt, because molt strategies in birds are

533 integral to their life history (e.g., Terrill, 2017, 2018) and are not predicted to be highly labile. In

534 contrast, concordant with our findings, studies on diverse taxa have shown that plumage

535 patterning is generally quite labile across avian clades (Omland \& Lanyon, 2000). Lability in this

536 trait is associated with a variety of biotic and abiotic attributes, such as variation in mating 
537 systems (Møller \& Birkhead, 1994; Price \& Whalen, 2009) and light environments (Shultz \&

538 Burns, 2013; Marcondes \& Brumfield, 2019). The species studied here all have similar

539 monogamous mating systems, but patterning was correlated with habitat across Passerellidae,

540 providing a potential selective factor shaping patterning. Future work studying this variability

541 would be informative.

542

543 Song structure, duetting, nest location, group breeding, skull ossification, and postjuvenal molt

544 are all traits with strong phylogenetic signals. The most highly conserved trait was duetting,

545 which was frequent across the tree but had few evolutionary origins. Both song structure and

546 duet type tended to be conserved, such that close relatives used similar sounds. Complex song is

547 often attributed to sexual selection (Andersson, 1994), while duetting is associated with pair

548 bond maintenance and territory defense (Logue \& Hall, 2014). For song structure, the

549 phylogenetic signal in our focal clades came primarily from the derivation and maintenance of

550 complex song in two lineages (Fig. 5). Conservation of complex song is sometimes found in

551 other groups (Price \& Lanyon, 2002; Tietze et al., 2015; but see Price et al., 2007). For this

552 study, we followed Wolf (1977) in defining song complexity based on the number and variety of

553 note types in the species-typical song. Although debate exists about what metrics of song best

554 describe “complexity” (Pearse et al, 2018; Najar \& Benedict, 2019; Benedict \& Najar, 2019),

555 increased complexity reflects higher syllable diversity in the species we studied and is conserved

556 in related lineages. This result might suggest that closely related species are under similar

557 selective pressures for maintenance of song structure, potentially relating to visual signaling or

558 habitat as discussed above (Panhuis et al., 2001; Boncoraglio \& Saino, 2007).

559 
560 Duet vocalizations are derived and maintained in many of the focal species in our study. Avian

561 duets have been shown to perform a range of functions, including joint resource defense, mate

562 defense, and pair coordination (Hall, 2009; Dahlin \& Benedict, 2014). Work on the genera

563 Melozone and Peucaea has demonstrated that duets of different species have similar functions in

564 resource defense, providing a possible selective pressure maintaining this trait (Benedict, 2010;

565 Illes, 2015; Sandoval et al., 2018). Similarly, studies of other New World avian clades have

566 shown that vocal duet presence and form are often evolutionarily conserved (Mann et al., 2009;

567 Mitchell et al., 2019). This pattern is likely driven by life-history traits such as monogamy,

568 territoriality, and sedentariness, which are shown by many of the species included in our analysis

569 (Benedict, 2008; Logue \& Hall, 2014). Most strikingly, duet type (Fig. 5) in addition to duet

570 presence is conserved, as noted by Wolf (1977). Our focal species therefore provide a valuable

571 system for future analyses examining how territorial behavior throughout the year and the length

572 of pair bonds might promote evolutionary stability in behavioral traits. Overall, the strong

573 phylogenetic signal found for vocal traits and other behaviors, including nest location and group

574 breeding, counters a general assumption that behavioral traits are more labile than morphological

575 traits (Blomberg et al. 2003).

576

\section{Conclusions}

578 Our study elucidated relationships among New World sparrows and showed that behavioral traits

579 such as vocal duetting and nest placement can exhibit stronger phylogenetic signal than

580 morphological traits. Habitat appears to be an important driver of trait evolution within

581 Aimophila and Peucaea, but its influence is not consistent within the Passerellidae. While habitat

582 does not predict song evolution reliably across New World sparrows, the correlations of 
583 unpatterned plumage with open habitats and complex songs does hold broadly in sparrows..

584 Outcomes suggest that New World sparrows provide a fertile testing ground for future studies of 585 avian trait evolution.

586

587 Acknowledgements

588 Sakina Palida assisted with the molecular lab work. Rauri Bowie helped with analyses and 589 comments, and Michael Patten and five anonymous reviewers provided comments that improved 590 earlier drafts of this paper. The Macaulay Library provided recordings on a CD, and the 591 University of California Berkeley Language Center digitized Wolf's (1977) recordings from LP.

592 We thank the curators and collections staff at the following museums for loans of tissue samples 593 used in this study and for providing information on voucher numbers (Supplemental Table S1):

594 Biodiversity Institute and Natural History Museum, University of Kansas (Town Peterson, Mark 595 Robbins); Burke Museum of Natural History and Culture, University of Washington (Sharon 596 Birks, John Klicka); Colección Nacional de Aves, Instituto de Biología, Universidad Nacional 597 Autónoma de México (Patricia Escalante); Field Museum of Natural History (John Bates, 598 Shannon Hackett, David Willard); Museo de Zoología de la Facultad de Ciencias, Universidad 599 Nacional Autónoma de México (Blanca Hernández, Adolfo Navarro); Museum of Natural 600 Science, Louisiana State University (Donna Dittman, Fred Sheldon); and Royal Ontario Museum 601 (Brad Millen).

602

603 References

604 American Ornithologists' Union. 1983. Check-list of North American Birds, $6^{\text {th }}$ edition.

605 American Ornithologists’ Union, Lawrence, KS. 
606 Anderson SR, Wiens JJ. 2017. Out of the dark: 350 million years of conservatism and

607 evolution in diel activity patterns in vertebrates. Evolution 71:1944-1959

608 Andersson MB. 1994. Sexual Selection. Princeton: Princeton University Press.

609 Badyaev A, Hill G, Weckworth B. 2002. Species divergence in sexually selected traits:

610 increase in song elaboration is related to decrease in plumage ornamentation in

611 finches. Evolution 56:412-419

612 Baird SF. 1858. Birds. In: Baird SF, CassinJ, Lawrence GN, eds. Pacific Railroad Reports. U.S.

613 Government, Washington.

614 Baltz ME, Latta SC. 1998. Cape May Warbler (Setophaga tigrina). In: Rodewald PG, ed. The

615 Birds of North America. Ithaca: Cornell Lab of Ornithology.

616 Barve S, Mason NA. 2015. Interspecific competition affects evolutionary links between cavity

617 nesting, migration and clutch size in Old World flycatchers (Muscicapidae). Ibis 157:299-311

618 Beaulieu JM, Oliver JC, O’Meara B. 2017. corHMM: Analysis of Binary Character Evolution.

619 R package version 1.22. https://CRAN.R-project.org/package=corHMM.

620 Benedict L. 2008. Occurrence and life history correlates of vocal duetting in North American

621 passerines. Journal of Avian Biology 39:57-65

622 Benedict L. 2010. California towhee vocal duets are multi-functional signals for multiple

623 receivers. Behaviour 147:953-978

624 Benedict L, Najar NA. 2019. Are commonly used metrics of bird song complexity concordant?

625 The Auk: Ornithological Advances 136:uky008

626 Blomberg SP, Garland T Jr, Ives AR. 2003. Testing for phylogenetic signal in comparative

627 data: behavioral traits are more labile. Evolution 57:717-745 
628 Boncoraglio G, Saino N. 2007. Habitat structure and the evolution of bird song: a meta-analysis

629 of the evidence for the acoustic adaptation hypothesis. Functional Ecology 21:134-142

630 Bouckaert R, Heled J, Kühnert D, Vaughan T, Wu C.-H, Xie D, Suchard M, Rambaut A,

631 Drummond A. 2014. BEAST 2: A Software Platform for Bayesian Evolutionary Analysis. -

632 PLoS Computational Biology 10: e1003537 doi:10.1371/journal.pcbi.1003537

633 Brumfield RT, Tello JG. Cheviron ZA, Carling MD, Crochet N., Rosenberg KV. 2007.

634 Phylogenetic conservatism and antiquity of a tropical specialization: Army-ant-following in the 635 typical antbirds (Thamnophilidae). Molecular Phylogenetics and Evolution 45:1-13

636 Brush T. 1998. Olive Sparrow (Arremonops rufivirgatus). In: Rodewald PG, ed. The Birds of

637 North America. Ithaca: Cornell Lab of Ornithology.

638 Bryson RW Jr, Faircloth BC, Tsai WLE, McCormack JE., Klicka J. 2016. Target

639 enrichment of thousands of ultraconserved elements sheds new light on early relationships within

640 New World sparrows (Aves: Passerellidae). The Auk 133:451-458

641 Byers C, Curson J, Olsson U. 1995. Sparrows and Buntings: A Guide to the Sparrows and

642 Buntings of North America and the World. Boston: Houghton Mifflin Company.

643 Camargo A, Avila LJ, Morando M, Sites JW Jr. 2012. Accuracy and precision of species

644 trees: Effects of locus, individual, and base pair sampling on inference of species trees in lizards

645 of the Liolaemus darwinii group (Squamata, Liolaemidae). Systematic Biology 61:272-288

646 Carson RJ, Spicer GS. 2003. A phylogenetic analysis of the emberizid sparrows based on three

647 mitochondrial genes. Molecular Phylogenetics and Evolution 29:43-57

648 Chesser RT, Banks RC, Barker FK, Cicero C, Dunn JL, Kratter AW, Lovette IJ, Rasmussen PC,

649 Remsen JV Jr, Rising JD, Stotz DF, Winker K. 2010. Fifty-first supplement to the American

650 Ornithologists' Union Check-list of North American Birds. The Auk 127:726-744

Peer] reviewing PDF | (2019:10:41954:2:0:NEW 1 May 2020) 
651 Cicero C, Johnson NK. 1998. Molecular phylogeny and ecological diversification in a clade of

652 New World songbirds (genus Vireo). Molecular Ecology 7:1359-1370

653 Cicero C, Johnson NK. 2001. Higher level phylogeny of New World vireos (Aves: Vireonidae)

654 based on sequences of multiple mitochondrial DNA genes. Molecular Phylogenetics and

655 Evolution 20:27-40

656 Cicero C, Johnson NK. 2002a. Phylogeny and character evolution in the Empidonax group of

657 tyrant flycatchers (Aves: Tyrannidae): a test of W. E. Lanyon's hypothesis using mtDNA

658 sequences. Molecular Phylogenetics and Evolution 22:289-302

659 Cicero C, Johnson NK. 2002b. The role of ecological diversification in sibling speciation of

660 Empidonax flycatchers (Tyrannidae): multigene evidence from mtDNA. Molecular Ecology

$661 \quad 11: 2065-2081$

662 Crouch NMA, Mason-Gamer RJ. 2019. Identifying ecological drivers of interspecific variation 663 in song complexity in songbirds (Passeriformes, Passeri). Journal of Avian Biology 2019:e02020

664 DaCosta JM, Spellman GM, Escalante P, Klicka J. 2009. A molecular systematic revision of

665 two historically problematic songbird clades: Aimophila and Pipilo. Journal of Avian Biology

666 40:206-216

667 Dahlin CR, Benedict L. 2014. Angry birds need not apply: a perspective on the flexible form 668 and multifunctionality of avian vocal duets. Ethology 120:1-10

669 De Queiroz A, Wimberger PH. 1993. The usefulness of behavior for phylogeny estimation:

670 levels of homoplasy in behavioral and morphological characters. Evolution 47:46-60

671 Derryberry EP. 2009. Ecology shapes bird song evolution: variation in morphology and habitat 672 explains variation in White-crowned Sparrow song. American Naturalist 174:24-33 
673 Derryberry EP, Seddon N, Derryberry GE, Claramunt S, Seeholzer GF, Brumfield RT,

674 Tobias JA. 2018. Ecological drivers of song evolution in birds: disentangling the effects of

675 habitat and morphology. Ecology and Evolution 8:1890-1905

676 Desjardins P, Morais R 1990. Sequence and gene organization of the chicken mitochondrial

677 genome. A novel gene order in higher vertebrates. Journal of Molecular Biology 212:599-634

678 Dickey DR, van Rossem AJ. 1938. The Birds of El Salvador. Chicago: Field Museum of

679 Natural History Zoological Series 23.

680 Dickinson EC, ed. 2003. The Howard and Moore Complete Checklist of the Birds of the World, $6813^{r d}$ Edition. United Kingdom: Christopher Helm.

682 Dobbs RC, Martin PR, Martin TE. 1998. Green-tailed Towhee (Pipilo chlorurus). In:

683 Rodewald PG, ed. The Birds of North America. Ithaca: Cornell Lab of Ornithology.

684 Dodd ME, Silvertown J, Chase MW. 1999. Phylogenetic analysis of trait evolution and species

685 diversity variation among angiosperm families. Evolution 53:732-744

686 Drummond AJ, Rambaut,A. 2007. BEAST: Bayesian evolutionary analysis by sampling trees.

687 BMC Evolutionary Biology 214:1-8

688 Drummond AJ, Suchard MA, Xie D, Rambaut A. 2012. Bayesian phylogenetics with BEAUti 689 and the BEAST 1.7. Molecular Biology and Evolution 29:1969-1973

690 Dunn PO, Armenta JK, Whittingham LA. 2015. Natural and sexual selection act on different 691 axes of variation in plumage color. Science Advances 1:e1400155

692 Emlen ST. 1997. Predicting family dynamics in social vertebrates. In: KrebsJR, Davies NB, eds.

693 Behavioural Ecology: An Evolutionary Approach. 4th edition. Oxford: Blackwell Publishing.

$694 \quad 228-252$. 
695 Falls JB, Kopachena JG. 1994. White-throated Sparrow (Zonotrichia albicollis). In: Rodewald 696 PG, ed. The Birds of North America. Ithaca: Cornell Lab of Ornithology.

697 Fang Y, Mao-Ning T, Chih-Ming H. 2018. Asynchronous evolution of interdependent nest 698 characters across the avian phylogeny. Nature Communications 9:1863

699 Felsenstein J. 2004. Inferring phylogenies. Sunderland: Sinauer Associates.

700 FitzJohn RG, Maddison WP, Otto SP. 2009. Estimating trait-dependent speciation and 701 extinction rates from incompletely resolved phylogenies. Systematic Biology 58:595-611

702 Fleischer RC, Olson SL, James HF., Cooper AC. 2000. Identification of the extinct Hawaiian 703 Eagle (Haliaeetus) by mtDNA sequence analysis. The Auk 117:1051-1056

704 Fritz SA, Purvis A. 2010. Selectivity in mammalian extinction risk and threat types: a new 705 measure of phylogenetic signal strength in binary traits. Conservation Biology 24:1042-1051

706 Grant PR, Grant BR. 2002. Unpredictable evolution in a 30-year study Darwin's Finches.

707 Science 296:707-711

708 Greenlaw JS. 1996a. Eastern Towhee (Pipilo erythrophthalmus). In: Rodewald PG, ed. The 709 Birds of North America. Ithaca: Cornell Lab of Ornithology.

710 Greenlaw JS. 1996b. Spotted Towhee (Pipilo maculatus). In: Rodewald PG, ed. The Birds of 711 North America. Ithaca: Cornell Lab of Ornithology.

712 Greenlaw JS, Rising JD. 1994. Saltmarsh Sharp-tailed Sparrow (Ammodramus caudacutus). In:

713 Rodewald PG, ed. The Birds of North America. Ithaca: Cornell Lab of Ornithology.

714 Hall ML. 2009. A review of vocal duetting in birds. Advances in the Study of Behavior 40:67$715 \quad 121$

716 Hamilton TH. 1962. Species relationships and adaptations for sympatry in the avian genus 717 Vireo. The Condor 64:40-68 
718 Hebert PDN, Stoeckle MY, Zemlak TS, Francis CM. 2004. Identification of birds through

719 DNA barcodes. PLoS Biology 2:1657-1663

720 Hill GE, McGraw KJ, eds. 2006. Bird Coloration: Function and Evolution. Volume 2.

721 Cambridge: Harvard University Press.

722 Hill SD, Pawley MDM, Ji W. 2017. Local habitat complexity correlates with song complexity

723 in a vocally elaborate honeyeater. Austral Ecology 42:590-596

724 Hilty S. 2003. Birds of Venezuela. 2nd edition. Princeton: Princeton University Press.

725 Hofmann, CM, Cronin TW, Omland KE. 2008. Evolution of sexual dichromatism. 1.

726 Convergent losses of elaborate female coloration in New World orioles (Icterus spp.). The

727 Auk 125:778-789

728 Howell SNG, Webb S. 1995. A Guide to the Birds of Mexico and Northern Central America.

729 Oxford: Oxford University Press.

730 Illes AE. 2015. Context of female bias in song repertoire size, singing effort, and singing 731 independence in a cooperatively breeding songbird. Behavioral Ecology and Sociobiology

$732 \quad 69: 139-150$

733 Irestedt M, Johansson US, Parsons TJ, Ericson PGP. 2001. Phylogeny of major lineages of

734 suboscines (Passeriformes) analysed by nuclear DNA sequence data. Journal of Avian Biology

$735 \quad 32: 15-25$

736 Johnson RR, Haight LT. 1996. Canyon Towhee (Pipilo fuscus). - In: Rodewald PG, ed. The

737 Birds of North America. Ithaca: Cornell Lab of Ornithology.

738 Johnson MJ, Van Riper C. III, Pearson KM, 2002. Black-throated Sparrow (Amphispiza

739 bilineata). In: Rodewald PG, ed. The Birds of North America. Ithaca: Cornell Lab of

740 Ornithology. 
741 Jones SL, Cornely JE. 2002. Vesper Sparrow (Pooecetes gramineus). In: Rodewald PG, ed.

742 The Birds of North America. Ithaca: Cornell Lab of Ornithology.

743 Kamilar JM, Cooper N. 2013. Phylogenetic signal in primate behaviour, ecology and life

744 history. Philosophical Transactions of the Royal Society B 368:20120341

745 Karin,BR, Cicero C, Koo MS, Bowie RCK. 2018. The role of history and ecology as drivers of

746 song divergence in Bell's and Sagebrush sparrows (Artemisiospiza, Aves: Passerellidae).

747 Biological Journal of the Linnean Society 125:421-440

748 Klicka J, Banks RC. 2011. A new generic name for some sparrows (Aves: Emberizidae).

749 Zootaxa 2793:67-68

750

751

752

753

754

755

756

757

758

759

760

761

762

763

Klicka J, Barker KF, Burns KJ, Lanyon SM, Lovette IJ, Chaves JA, Bryson RW Jr. 2014.

A comprehensive multilocus assessment of sparrow (Aves: Passerellidae) relationships.

Molecular Phylogenetics and Evolution 77:177-182

Klicka J, Spellman G. 2007. A molecular evaluation of the North American "Grassland" sparrow clade. The Auk 124:537-551

Knapton RW. 1994. Clay-colored Sparrow (Spizella pallida). In: Rodewald PG, ed. The Birds of North America. Ithaca: Cornell Lab of Ornithology.

Kunzmann MR, Ellison K, Purcell KL, Johnson RR, Haight LT. 2002. California Towhee (Pipilo crissalis). In: Rodewald PG, ed. The Birds of North America. Ithaca: Cornell Lab of Ornithology.

Lanyon WE. 1984. A phylogeny of the kingbirds and their allies. American Museum Novitates 2797:1-28

Lanyon WE. 1985. A phylogeny of the myiarchine flycatchers. In Buckley PA, Foster MS, Morton ES, eds. Neotropical Ornithology. Ornithological Monographs 36:361-380 
764 Lanyon WE. 1986. A phylogeny of the thirty-three genera in the Empidonax assemblage of

765 tyrant flycatchers. American Museum Novitates 2846:1-64

766 Lanyon WE. 1988a. A phylogeny of the thirty-two genera in the Elaenia assemblage of tyrant

767 flycatchers. American Museum Novitates 2914:1-57

768 Lanyon WE. 1988b. A phylogeny of the flatbill and tody-tyrant assemblage of tyrant

769 flycatchers. American Museum Novitates 2923:1-41

770 Lenormand T. 2012. From local adaptation to speciation: Specialization and reinforcement.

771 International Journal of Ecology 2012, Article ID 508458, 11 pages.

772 Logue DM, Hall ML. 2014. Migration and the evolution of duetting in songbirds. Proceedings

773 of the Royal Society B: Biological Sciences 281:20140103

774 Lowther PE. 1993. Brown-headed Cowbird (Molothrus ater). In: Rodewald PG, ed. The Birds 775 of North America. Ithaca: Cornell Lab of Ornithology.

776 Lowther PE. 2005. Le Conte's Sparrow (Ammodramus leconteii). In: Rodewald PG, ed. The Birds 777 of North America. Ithaca: Cornell Lab of Ornithology.

778 Maddison DR. 1994. Phylogenetic methods for inferring the evolutionary history and processes

779 of change in discretely valued characters. Annual Review of Entomology 39:267-292

780 Maddison WP, FitzJohn RG. 2015. The unsolved challenge to phylogenetic correlation tests

781 for categorical characters. Systematic Biology 64:127-136.

782 Maddison WP, Maddison DR. 2003. Mesquite: A Modular System for Evolutionary Analysis.

783 Version 1.0. http://www.mesquiteproject.org

784 Maddison DR, Maddison WP. 2018. Pagel's Correlation Method. Mesquite Version 3.6.

785 http://www.mesquiteproject.org/Pagel\%20Correlation\%20Method.html 
786 Maddison WP, Midford PE, Otto SP. 2007. Estimating a Binary Character's Effect on

787 Speciation and Extinction. Systematic Biology 56:701-710

788

789

790

791

792

793

794

795

796

797

798

799

800

801

802

803

804

805

806

807

Maia R, Rubenstein DR, Shawkey MD. 2016. Selection, constraint, and the evolution of

coloration in African starlings. Evolution 70:1064-1079

Mann NI, Dingess KA, Barker FK, Graves JA, Slater PJB. 2009. A comparative study of song form and duetting in neotropical Thryothorus wrens. Behaviour 146:1-43

Marcondes RS, Brumfield RT. 2019. Fifty shades of brown: macroevolution of plumage

brightness in the Furnariida, a large clade of drab Neotropical passerines. Evolution 73: 704-719

Marini MA, Hackett SJ. 2002. A multifaceted approach to the characterization of an

intergeneric hybrid manakin (Pipridae) from Brazil. The Auk 119:1114-1120

Marshall JT. 1964. Voice in communication and relationships among brown towhees. The

Condor 66:345-356

Martin JW, Carlson BA. 1998. Sage Sparrow (Amphispiza belli). In: Rodewald PG, ed. The Birds of North America. Ithaca: Cornell Lab of Ornithology.

Martin JW, Parrish JR. 2000. Lark Sparrow (Chondestes grammacus). In: Rodewald PG, ed. The Birds of North America. Ithaca: Cornell Lab of Ornithology.

Mason NA, Burns KJ. 2015. The effect of habitat and body size on the evolution of vocal displays in Thraupidae (tanagers), the largest family of songbirds. Biological Journal of the Linnean Society 114:538-551

Mason NA, Shultz AJ, Burns KJ. 2014. Elaborate visual and acoustic signals evolve independently in a large, phenotypically diverse radiation of songbirds. Proceedings of the Royal Society B 281:20140967 
808 Medina I, Francis CD. 2012. Environmental variability and acoustic signals: a multi-level

809 approach in songbirds. Biology Letters 23:928-931

810 Middleton AL. 1998. Chipping Sparrow (Spizella passerina). In: Rodewald PG, ed. The Birds of 811 North America. Ithaca: Cornell Lab of Ornithology.

812 Miller ET, Leighton GM, Freeman BG, Lees AC, Ligon RA. 2019. Ecological and geographical 813 overlap drive plumage evolution and mimicry in woodpeckers. Nature Communications 10:1602

814 Miller MA, Pfeiffer W, Schwartz T. 2010. Creating the CIPRES Science Gateway for

815 inference of large phylogenetic trees. In: Proceedings of the Gateway Computing Environments

816 Workshop (GCE). New York: Institute of Electrical and Electronics Engineers, Inc.

$817 \quad \underline{10.1109 / G C E .2010 .5676129}$

818 Miller SA, Dykes DD, Polesky HF. 1988. A simple salting out procedure for extracting DNA 819 from human nucleated cells. Nucleic Acids Research 16:1215

820 Mitchell LR, Benedict L, Cavar J, Najar N, Logue DM. 2019. The evolution of vocal duets 821 and migration in New World warblers (Parulidae). The Auk: Ornithological Advances

822 136:ukz003

823 Møller AP, Birkhead TR. 1994. The evolution of plumage brightness in birds is related to 824 extrapair paternity. Evolution 48:1089-1100

825 Mooers A Ø, Vamosi SM, Schluter D. 1999. Using phylogenies to test macroevolutionary

826 hypotheses of trait evolution in Cranes (Gruinae). American Naturalist 154:249-259

827 Morton ES. 1975. Ecological sources of selection on avian sounds. American Naturalist 109:17$828 \quad 34$

829 Najar N, Benedict L. 2019. The relationship between latitude, migration and the evolution of 830 bird song complexity. Ibis 161:1-12 
831 Nylander JAA. 2004. MrModeltest. Version 2.3. Uppsala: Evolutionary Biology Centre,

832 Uppsala University.

833 Omland KE, Lanyon SM. 2000. Reconstructing plumage evolution in Orioles (Icterus):

834 Repeated convergence and reversal in patterns. Evolution 54:2119-2133

835 Orme D. 2018. The caper package: Comparative analysis of phylogenetics and evolution in R.

$836 \mathrm{https}: / /$ rdrr.io/cran/caper/man/caper-package.html

837 Pagel M. 1994. Detecting correlated evolution on phylogenies: a general method for the 838 comparative analysis of discrete characters. Proceedings of the Royal Society of London B

$839 \quad 255: 37-45$

840 Panhuis TM, Butlin R, Zuk M, Tregenza T. 2001. Sexual selection and speciation. Trends in 841 Ecology and Evolution 16:364-371

842 Patten MA, Fugate M. 1998. Systematic relationships among the Emberizid sparrows. The Auk

$843 \quad$ 115:412-424

844 Pearse WD, Morales-Castilla I, James LS, Farrell M, Boivin F, Davies TJ. 2018. Complexity

845 is complicated and so too is comparing complexity metrics-A response to Mikula et al.(2018).

846 Evolution 72:2836-2838

847 Petit LJ. 1999. Prothonotary Warbler (Protonotaria citrea). In: Rodewald PG, ed. The Birds of 848 North America. Ithaca: Cornell Lab of Ornithology.

849 Phillips AR, Farfan RP. 1993. Distribution, migration, ecology, and relationships of the Five850 striped Sparrow, Aimophila quinquestriata. Western Birds 24:65-72

851 Price JJ, Friedman NR, Omland KE. 2007. Song and plumage evolution in the New World 852 orioles (Icterus) show similar lability and convergence in patterns. Evolution 61:850-863 
853 Price JJ, Lanyon SM. 2002. Reconstructing the evolution of complex bird song in the

854 oropendolas. Evolution 56:1514-1529

855 Price JJ, Lanyon SM. 2004. Patterns of song evolution and sexual selection in the oropendolas 856 and caciques. Behavioral Ecology 15:485-497

857 Price JJ, Whalen LM. 2009. Plumage evolution in the oropendolas and caciques: Different 858 divergence rates in polygynous and monogamous taxa. Evolution 63:2985-2998

859 Pyle P. 1997. Identification Guide to North American Birds, Part I. Bolinas: Slate Creek Press. 860 Pyron RA, Costa GC, Patten MA, Burbrink FT. 2015. Phylogenetic niche conservatism and 861 the evolutionary basis of ecological speciation. Biological Reviews 90:1248-1262.

Remsen JV Jr, Areta JI, Cadena CD, Jaramillo A, Nores M, Pacheco J F, Pérez-Emán J, 863 Robbins MB, Stiles FG, Stotz DF, Zimmer K. J. 2010. A classification of the bird species of 864 South America. Chicago: American Ornithological Society.

865 http://www.museum.lsu.edu/ Remsen/SACCBaseline.html

866 Revell LJ, Harmon LJ, Collar DC. 2008. Phylogenetic signal, evolutionary process, and rate.

867 Systematic Biology 57:591-601

868 Ridgely RS, Tudor G. 1994. The Birds of South America. Vol. 2: The Suboscine Passerines.

869 Austin: University of Texas Press.

870 Ridgway R. 1901. The Birds of North and Middle America. Washington, D.C.: Bulletin of the

871 United States National Museum.

872 Rising JD, Williams PL. 1999. Bullock's Oriole (Icterus bullockii). In: Rodewald PG, ed. The 873 Birds of North America. Ithaca: Cornell Laboratory of Ornithology.

874 Rodewald PG (ed). 2015. The Birds of North America. Ithaca: Cornell Lab of Ornithology. 875 https://birdsna.org 
876 Sandoval L, Epperly KL, Klicka J, Mennill DJ. 2017. The biogeographic and evolutionary

877 history of an endemic clade of Middle American sparrows: Melozone and Aimophila (Aves:

878 Passerellidae). Molecular Phylogenetics and Evolution 110:50-59

879 Sandoval L, Juárez R, Villarreal M. 2018. Different messages are transmitted by individual 880 duet contributions and complete duets in a species with highly overlapped duets. The Open 881 Ornithology Journal 11:56-67

882 Sandoval L, Méndez C, Mennill DJ. 2013. Different vocal signals, but not prior experience, 883 influence heterospecific from conspecific discrimination. Animal Behaviour 85:907-915

884 Shultz AJ, Burns KJ. 2013. Plumage evolution in relation to light environment in a novel clade 885 of Neotropical tanagers. Molecular Phylogenetics and Evolution 66:112-125

886 Shultz AJ, Burns KJ. 2017. The role of sexual and natural selection in shaping patterns of 887 sexual dichromatism in the largest family of songbirds (Aves: Thraupidae). Evolution 71:1061$888 \quad 1074$

889 Shutler D. 2010. Sexual selection: When to expect trade-offs. Biology Letters 7:101-104

890 Snyder KT, Creanza N. 2019. Polygyny is linked to accelerated birdsong evolution but not to 891 larger song repertoires. Nature Communications 10: 884

892 Somveille M, Marshall KLA, Gluckman T-L. 2016. A global analysis of bird plumage 893 patterns reveals no association between habitat and camouflage. PeerJ 4:e2658

894 Sorenson MD, Balakrishnan CN, Payne RB. 2004. Clade-limited colonization in brood 895 parasitic finches (Vidua spp.). Systematic Biology 53:140-153

896 Stamatakis A. 2006. RAxML-VI-HPC: Maximum likelihood-based phylogenetic analyses with 897 thousands of taxa and mixed models. Bioinformatics 22:2688 
898 Stamatakis A, Hoover P, Rougemont J. 2008. A rapid bootstrap algorithm for the RAxML

899 Web servers. Systematic Biology 57:758-771

900 Stevens, GC. 1989. The latitudinal gradient in geographical range: how so many species coexist 901 in the tropics. The American Naturalist 133:240-256

902 Storer RW. 1955. A preliminary survey of the sparrows of the genus Aimophila. The Condor $903 \quad 57: 193-201$

904 Swainson W. 1837. On the Natural History and Classification of Birds. London: Longman, 905 Rees, Orme, Brown, Green, Longman, Taylor.

906 Tenney CR. 1997. Black-chinned Sparrow (Spizella atrogularis). In: Rodewald PG, ed. The Birds 907 of North America. Ithaca: Cornell Lab of Ornithology.

908 Terrill RS. 2017. Evolutionary interactions of feather molt in birds. Louisiana State University 909 Doctoral Dissertations 4419. https://digitalcommons.1su.edu/gradschool_dissertations

910 Terrill R S. 2018. Feather growth rate increases with latitude in four species of widespread 911 resident Neotropical birds. The Auk: Ornithological Advances 135:1055-1063

912 Thompson CW. 1991. The sequence of molts and plumages in Painted Buntings and 913 implications for theories of delayed plumage maturation. The Condor 93:209-235

914 Tietze DT, Martens J, Fischer BS, Sun YH, Klussmann-Kolb A, Päckert M. 2015. Evolution 915 of leaf warbler songs (Aves: Phylloscopidae). Ecology and evolution 5:781-798Vickery PD. 916 1996. Grasshopper Sparrow (Ammodramus savannarum). In: Rodewald PG, ed. The Birds of 917 North America. Ithaca: Cornell Lab of Ornithology.

918 Wheelwright NT, Rising JD. 2008. Savannah Sparrow (Passerculus sandwichensis). In: 919 Rodewald PG, ed. The Birds of North America. Ithaca: Cornell Lab of Ornithology. 
920 Wiley RH. 1991. Associations of song properties with habitats for territorial oscine birds of 921 eastern North America. American Naturalist 138:973-993

922 Winger BM, Barker FK, Ree RH. 2014. Temperate origins of long-distance seasonal migration 923 in New World songbirds. Proceedings of the National Academy of Sciences 111:12115-12120

924 Willoughby EJ. 1991. Molt of the genus Spizella (Passeriformes, Emberizidae) in relation to 925 ecological factors affecting plumage wear. Proceedings of the Western Foundation of Vertebrate 926 Zoology 4:247-286

927 Wolf LJ. 1977. Species relationships in the avian genus Aimophila. Ornithological Monographs 928 No. 23 (with accompanying LP of audio recordings). Lawrence: American Ornithologists Union. 


\section{Figure 1}

Concatenated analysis of phylogenetic relationships in the Passerellidae.

Maximum clade credibility tree for concatenated analysis ( 4 mitochondrial and 3 nuclear genes) and all taxa using BEAST. Asterisks indicate posterior probability values of 0.95 or higher. Taxa in black were originally classified as Aimophila prior to recent revision (DaCosta et al. 2009). The two clades outlined by boxes are the focus of detailed analyses of trait evolution. Bird illustrations are provided courtesy of Lynx Edicions. 


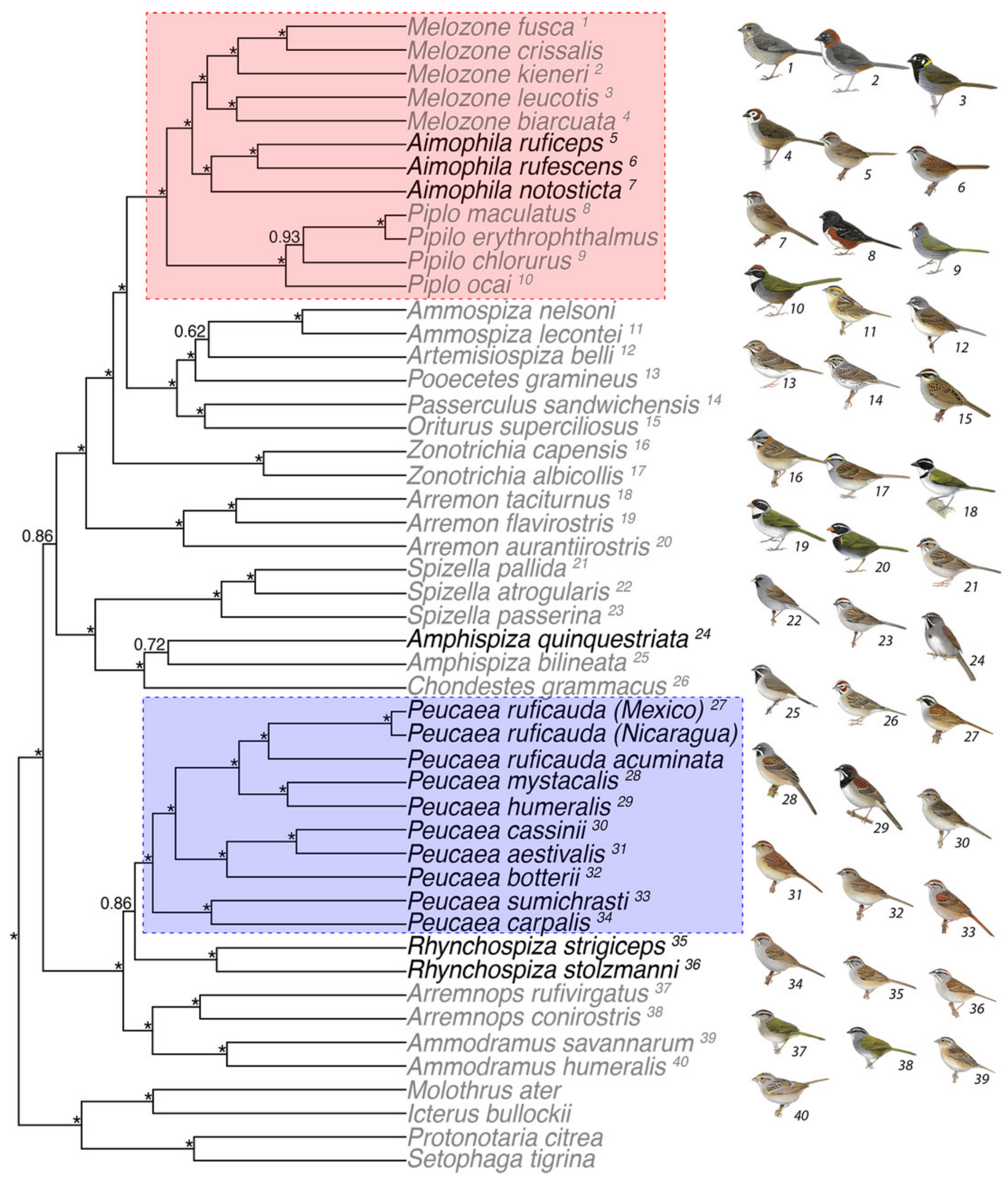


Figure 2

Trait reconstructions for geographic distribution and range size in two focal clades.

Maximum-likelihood based trait reconstructions of geographic distribution and range size among the Peucaea and Aimophila clades. Multiple colors at branch tips indicate the presence of multiple character states. Multiple colors on nodes indicate the probability of each character state. 


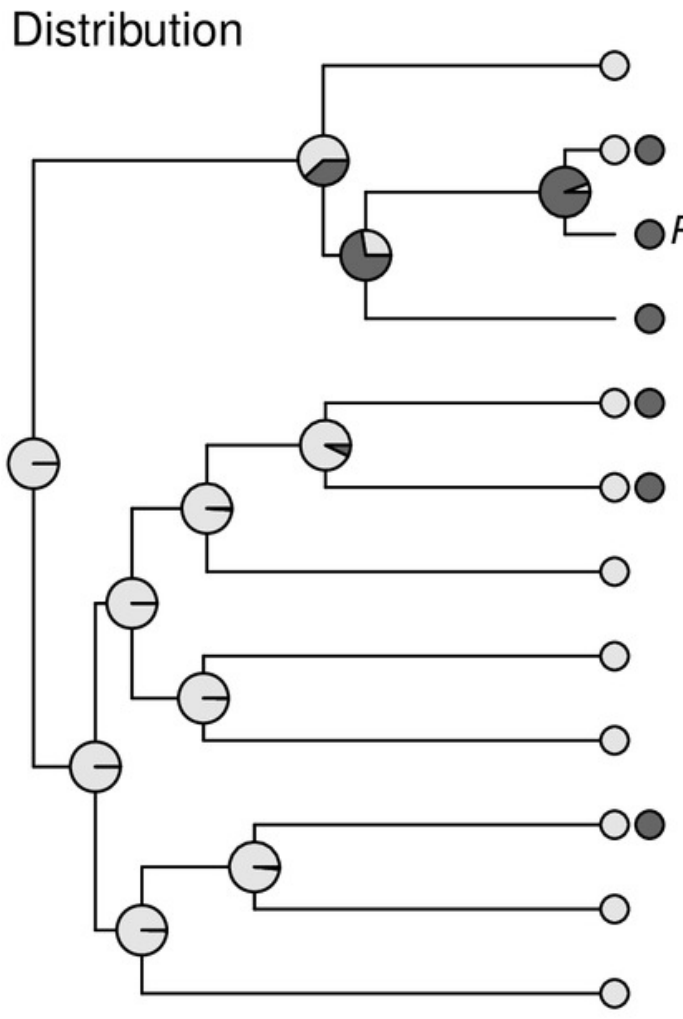

Pipilo ocai
Pipilo maculatus
Pipilo erythrophthalmus
Melozone fusca
Melozone crissalis
Melozone kieneri
Melozone leucotis
Melozone biarcuata
Aimophila ruficeps
Aimophila rufescens
Aimophila notosticta
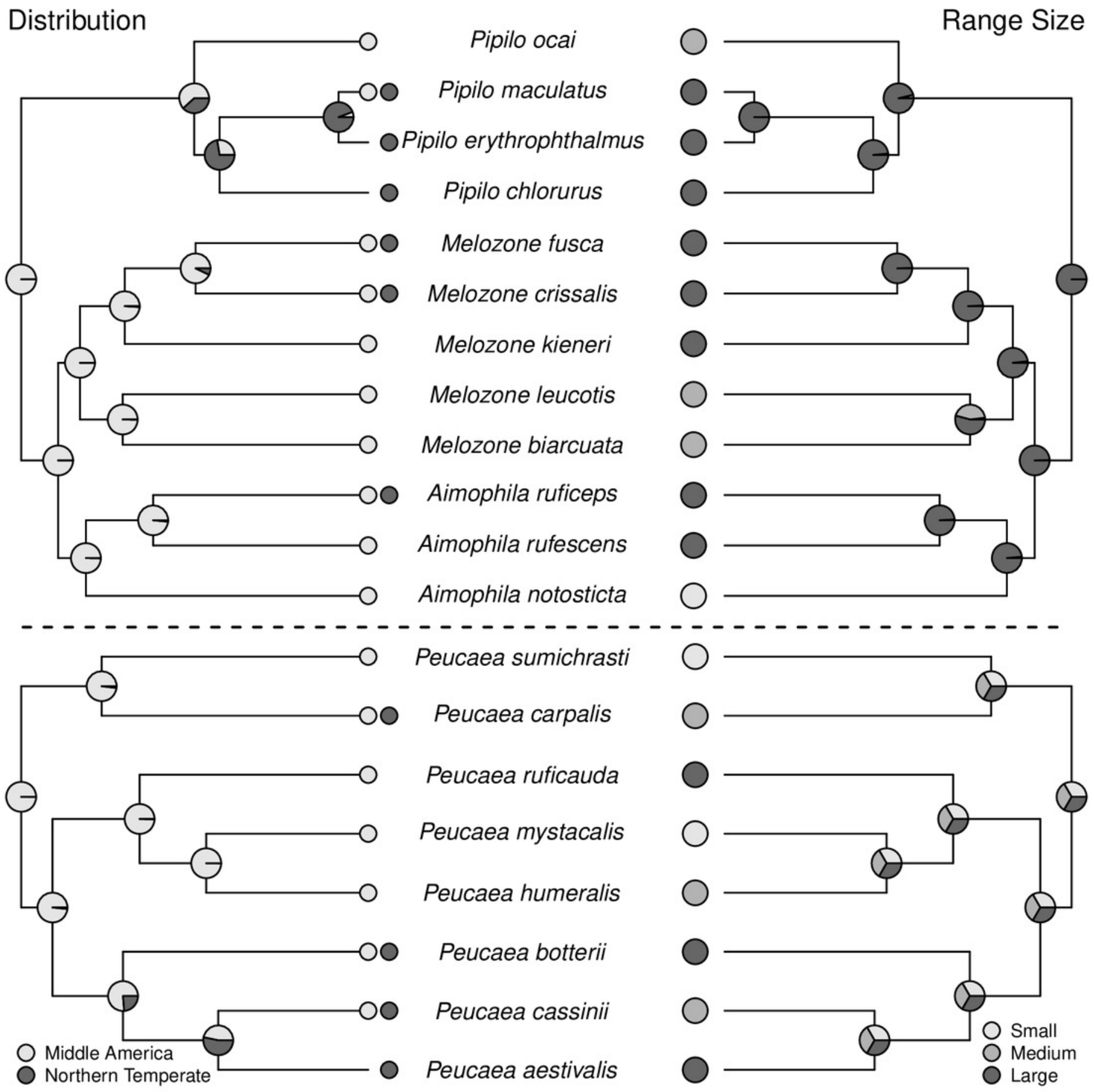

Peucaea sumichrasti

Peucaea carpalis

0

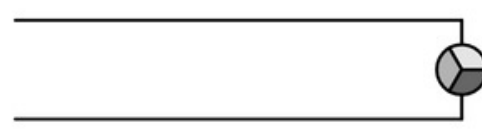

Peucaea ruficauda

Peucaea mystacalis

Peucaea humeralis

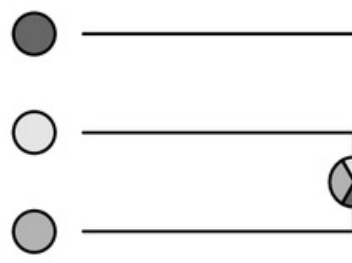

Peucaea botterii

Peucaea cassinii

Peucaea aestivalis

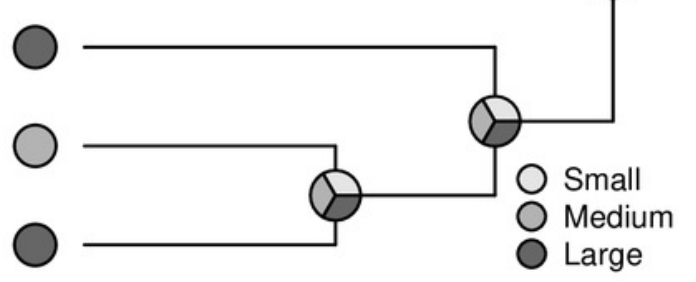


Figure 3

Trait reconstructions for habitat type and nest placement in two focal clades.

Maximum-likelihood based trait reconstructions of habitat type and nest placement among the Peucaea and Aimophila clades. Multiple colors at branch tips indicate the presence of multiple character states. Multiple colors on nodes indicate the probability of each character state. 

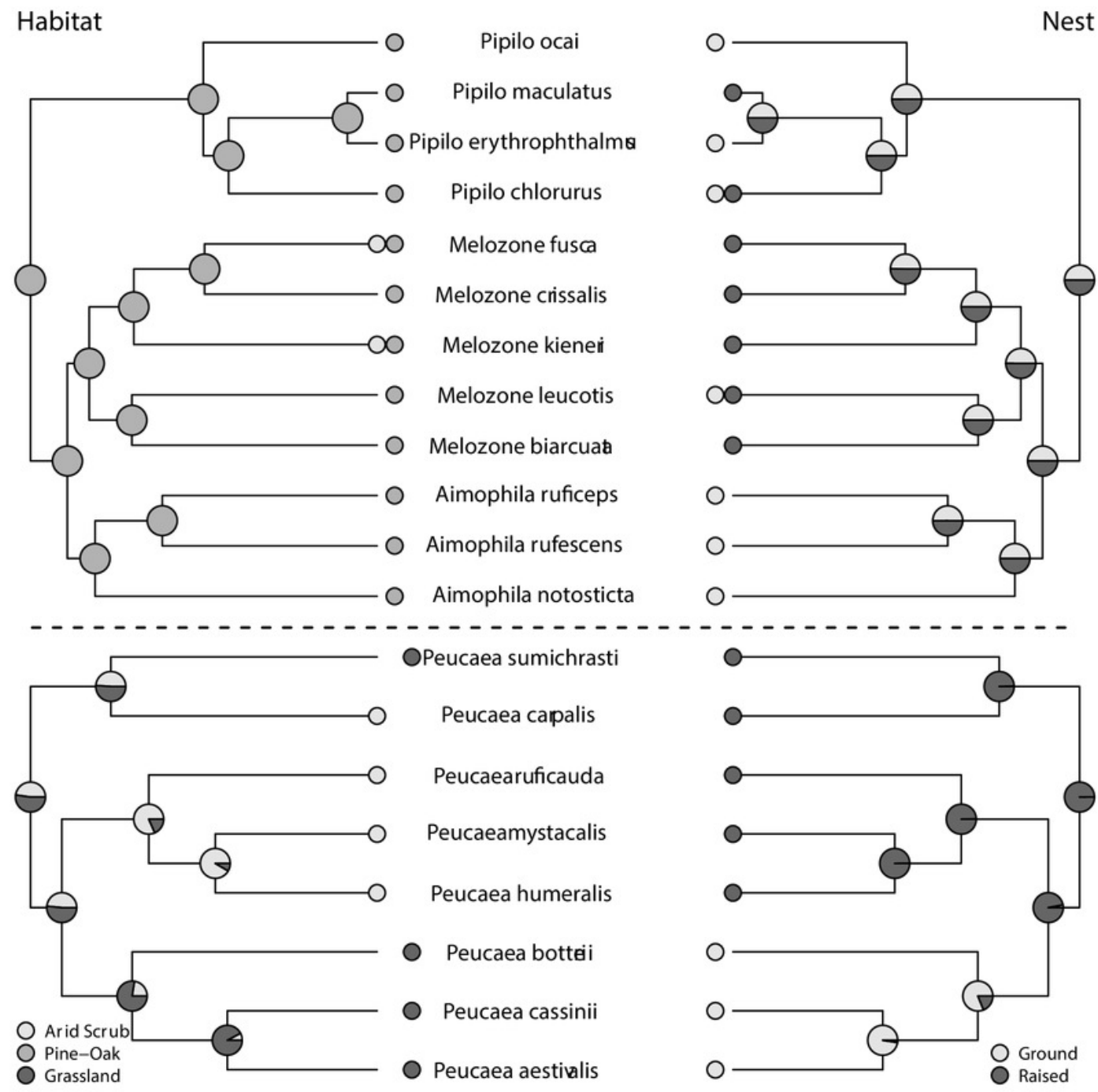


\section{Figure 4}

Trait reconstructions for plumage patterning and prenuptial molt in two focal clades.

Maximum-likelihood based trait reconstructions of plumage patterning and presence or absence of a prenuptial molt among the Peucaea and Aimophila clades. Multiple colors at branch tips indicate the presence of multiple character states. Multiple colors on nodes indicate the probability of each character state. 


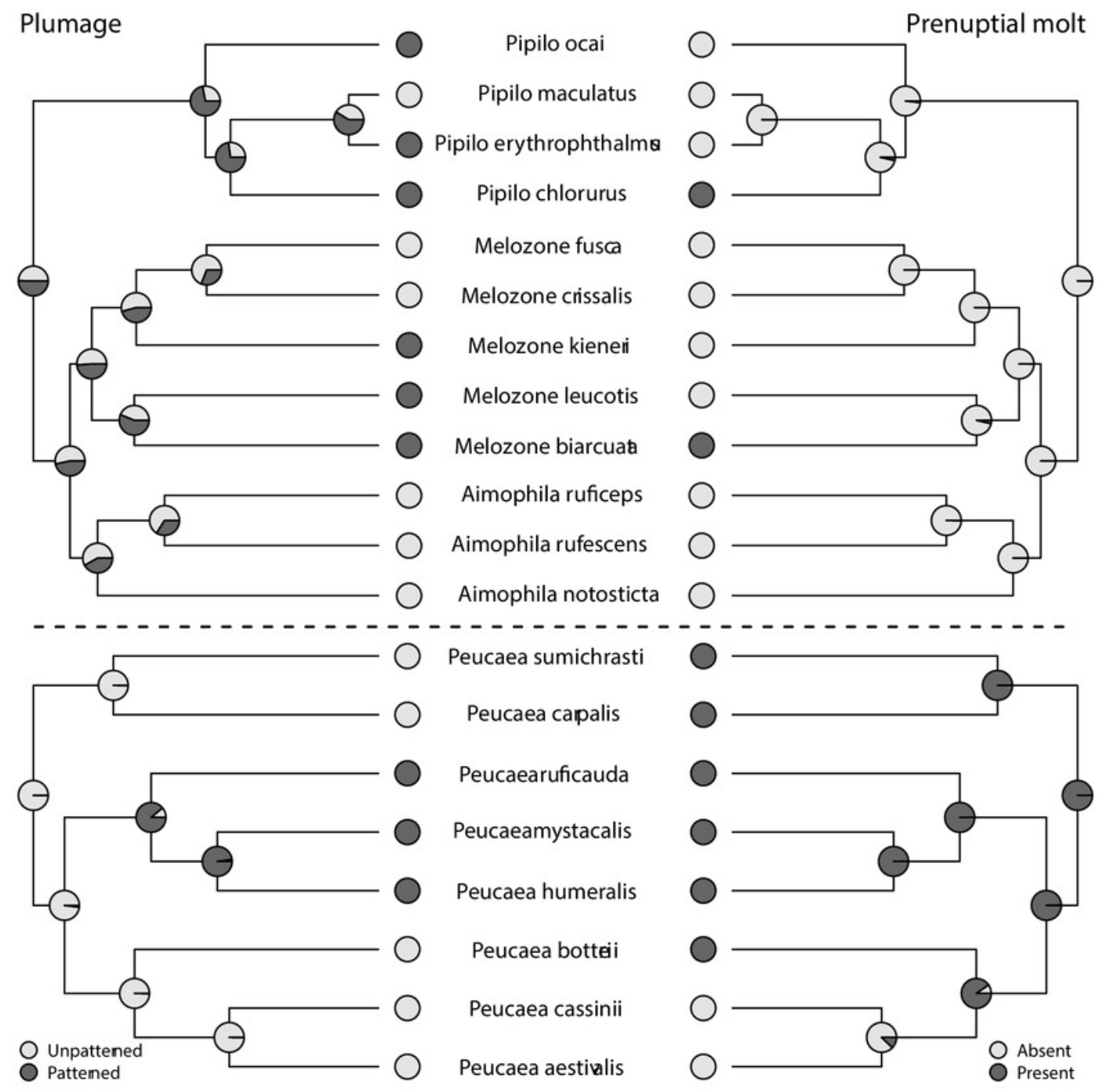




\section{Figure 5}

Trait reconstructions for song structure and duet type in two focal clades.

Maximum-likelihood based trait reconstructions of song structure and duet type among the Peucaea and Aimophila clades. Multiple colors at branch tips indicate the presence of multiple character states. Multiple colors on nodes indicate the probability of each character state. 


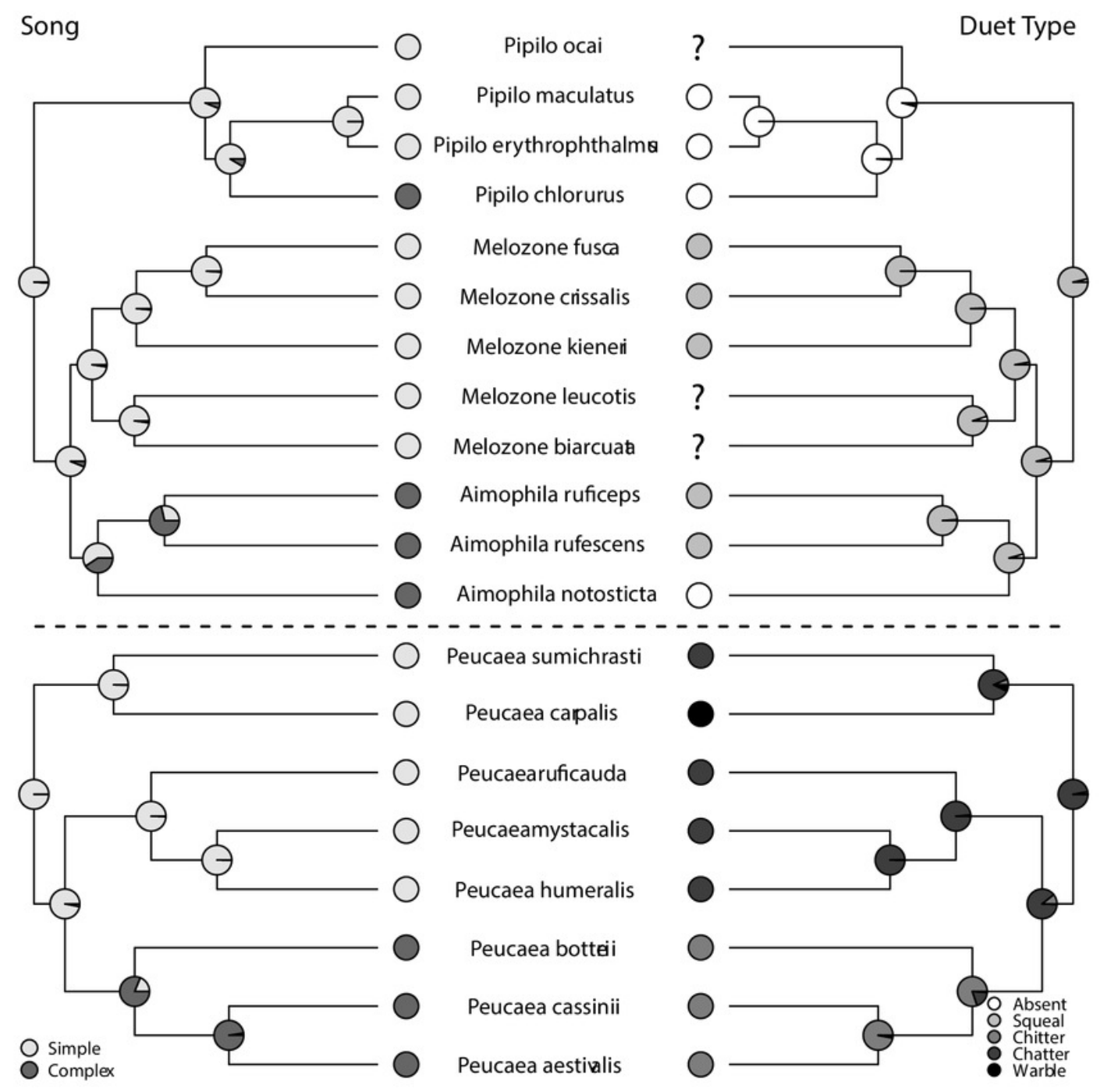




\section{Table 1 (on next page)}

Estimates of sister-clade differences and binary trait lability.

Estimates of the sum of sister-clade differences and trait lability ( $D$ statistic) in binary behavioral and morphological traits across the phylogeny depicted in Figure 1. 
1 Table 1: Estimates of phylogenetic signal and the sum of sister-clade differences in binary

2 behavioral and morphological traits using the phylogeny depicted in Figure 1. The $D$ statistic

3 indicates the amount of phylogenetic signal present in the binary trait. When $D=0$, the

4 phylogenetic signal of a given trait is equal to Brownian motion. When $D=1$, trait evolution is

5 random with respect to phylogeny. Thus, more negative $D$ values indicate stronger phylogenetic

6 signal and fewer changes between sister clades, while higher $D$ values indicate less signal and

7 more changes between sister clades. Values in the $\mathrm{P}_{\mathrm{D}>0}$ column indicate the probability that trait

8 evolution exhibits less phylogenetic signal compared to a null distribution of values under

9 Brownian motion. Values in the $\mathrm{P}_{\mathrm{D}<1}$ column indicate the probability that trait evolution exhibits

10 more phylogenetic signal compared to a null distribution of values when trait evolution is

11 random with respect to phylogeny. Each null distribution was generated with 1000 permutations.

12

\# of Taxa $\begin{gathered}\text { Sum of sister- } \\ \text { clade differences }\end{gathered} \quad$ D statistic $\quad \mathrm{P}_{\mathrm{D}>0} \quad \mathrm{P}_{\mathrm{D}<1}$

\section{Behavioral traits}

Group breeding

0.16

0.51

Nest position

Song type

46

10.00

$-1.25$

0.96

0.00

Duetting

39

7.28

$-1.72$

0.99

0.00

Mean $=8.85 \quad$ Mean $=-0.71$

\section{Morphological traits}

Postjuvenal molt 35

6.83

$-0.93$

0.84

0.01

Prenuptial molt

42

15.13

0.34

0.32

0.09

Plumage brightness

47

27.54

0.56

0.00

0.00

Skull ossification

33

5.69

$-1.21$

0.88

0.00

$$
\text { Mean }=13.80 \quad \text { Mean }=-0.31
$$

